\title{
東京大都市圈周辺地域における居住地移動の特性
}

一千葉市を事例として——

\section{山田浩 久*}

\section{Iはじめに}

1990 年の住民基本台帳によれば，全国の人口は 約 12,200 万人であり，そのうちの $25 \%$ に当たる 3,100 万人が東京, 神奈川, 千葉, 埼玉の 4 都県に 居住している. 東京大都市圈への人口の集中は, 1950 年代から 1970 年代前半にかけて急速に進行し, 1970 年代後半以降は鎮静化してきているが, 1989 年の社会増減数をみると, 神奈川県, 埼玉県, 千葉 県では依然として増加傾向を示している. 従来, こ のような東京近郊における社会増は, 東京からの人 口の郊外化として捉えられてきた。 しかしながら， 東京近郊において新たな都市化中心が形成され，東 京大都市圈における求心的な地域構造の弱体化が多 くの研究者によって指摘されている現在 ${ }^{11}$, 東京近 郊の社会増を人口の郊外化として捉えるだけでは, 東京大都市圈の拡大について議論することはできて も, 地域構造の変化に伴う東京と周辺地域との新た な関係について議論することはできない（藤井, 1983). 人口の郊外化に続いて生じた雇用の郊外化 によって, 周辺地域の都市は東京通勤者のためのべ ットタウンとしての機能以外の機能をもつようにな ってきているからである.

東京大都市圈の居住地移動に関する従来の研究を みると, 岸本 (1975) は, 入居率と通勤率から東京 大都市圏における居住地移動を考察し, 高度経済成 長期における周辺地域の人口増加は, 東京通勤者に よる東京区部から周辺地域への移動が主であり, 移
動距離は通勤距離によって規制されると述べている また，渡辺（1978c）は，移動者のライフステージ の変化による住み替えを移動理由や住居形態から分 析し, 東京区部から周辺地域への移動の多くは; 結 婚, 出産によって居住スペースの拡大が必要となる 30 歳台の移動であることを指摘した. このような ライフステージの変化に伴う居住地移動のパターン は，OD デー夕を使用した計量的な分析によっても 明らかにされている（矢野，1989）。さらに，蒲生 （1979）は，東京区部からの居住地移動を東部之西 部に分けて考察した。彼は, 区部西部からの移動の 着地が比較的広範囲に分散しているのに対し，区部 東部からの移動は埼玉，千葉方面へ極端に偏ってい ることを示して, 区部東部からの移動には Adams （1969）によって指摘された扇形状の方向偏倚が観 察されることを報告している。 これらの研究は，東 京大都市圈における人口の郊外化の特性を把握する うえで重要な研究例であるが，いずれも周辺地域の 都市は東京からの人口の受け㿼としてしか扱われて いない。

そこで, 本研究では, 東京大都市圈全体の居住地 移動の空間的パターンと移動者属性との関係を明ら かにする研究の一環として, 東京大都市圈において 新たな都市化中心となりつつある千葉市を事例に, 周辺地域で生じている居住地移動の方向と距離に関 して分析を行ない，その特性を明らかにすることを 目的とする. 


\section{II 使用データと分析方法}

居住地移動は，2つに分けて考える必要がある. 1 つは, 転勤, 転職, 就職といった職業的理由に基 づく居住地移動であり，もう1つは，住環境の改善 をおもな理由とした居住地移動である（Clark, 1985). 前者の移動は, その移動理由から明らかな ように，移動先決定までの時間が短く，移動者は移 動先に対する知識が浅いまま移動先を決定する. そ のため, 選択の自由度も低く, 移動者の属性や意識 が移動先に反映されにくい，一方，後者の移動は, 通勤時間による距離的制約を受けるため前者の移動 に比べて短距離の移動として観察される.この移動 は, 移動者がある程度の知識をもっている地域の中 で新住居の探索行動を行なうことができるほか, 移 動决定を遅らせたり取りやめたりすることが可能で あり, 選択の自由度は高い. 人口問題研究所による 1971 年の調査によれば, 東京大都市圈（東京区部 への通勤率が $5 \%$ 以上の市町村）に居住する移動経 験者の $36.2 \%$ が生活環境上の理由によって居住地 移動を行なっており, 東京大都市圏における移動理 由の第 1 位となっている (人口問題研究所, 1991)2).

本研究では，この住環境の改善を移動理由とする 居住地移動（以下，住居移動と呼ぶ）を分析対象之 し，そのデータを得るために，アンケート調査を行 なった。調査は 1987 年 7 月に千葉市の 8 つの中学 校にアンケート用紙を配布し，中学生の父母に居住 地移動に関する項目について質問を行なった，中学 校は, JR 線沿線に 4 校, 中心市街地 (JR 千葉駅 周辺）に 1 校, 学区に鉄道駅を含まない内陸部に 3 校選定した．質問項目は，移動前後の住所，前住居 を出た理由および現住居を選んだ理由 ${ }^{3)}$ ，移動時に おける世帯主年齢および世帯人員, 前住居における 居住年数, 移動時期, 移動前後の住居形態, 移動前 後の部屋数 (LDK, DK を除く), 居住地決定の際 に利用した情報源，探索行動時にのぼった候補地の
数（現居住地を除く）, 自家用車の有無, 世帯主の 就業地についてである. 移動主体という点では, 個々の世帯構成員にまでさかのぼった調査が必要で あるが，一般に世帯の移動は世帯主の意志が最も大 きな影響力をもつと考えられることやアンケート調 査の制約から移動世帯全体に関する項目之世帯主の 属性をもって世帯属性とし，移動世帯の特性を示す 指標とした．また，調査票を中学校に配布したため に, 分析対象が中学生を子供にもつ一般世帯に限定 されてしまい，老年層や単身者の移動デー夕を得る ことができなかった．以下に進める議論が，30 歳 台および 40 歳台を中心とした壮年層を世帯主にも つ世帯に関するものであることには注意しなければ ならない，単身者，老年層の居住地移動については， 今回の分析とは別に稿を改めて論じてみたい，配布 した調査票は 2, 312 枚であり, 回収票は 1, 607 枚 （69.5\%）であった，第 1 表は，回収票の内訳を示 したものである. 今回の分析では，千葉市の市域を 越えて住居移動を行なった 491 世帯のうち，すべて の質問項目に回答があった 444 世帯を対象とする. 回答漏れの世帯を除外したのは, アンケート結果に 数量化 I 類を適用する関係上, 各質問項目之も回答 世帯の合計が一致する必要があったためである。

以下，第亚章で国勢調查の結果から千葉市への人 口流入を概観した後, 第IV章でアンケート結果から 前居住地別に移動方向による移動世帯の属性の差異 について考察し, 第 $\mathrm{V}$ 章で移動距離と移動世帯の属 性との関係について数量化 I 類の分析を行ない，第 VI章でまとめる.

第 1 表 居住地移動の類型別集計 Table 1 Classification of the migration

\begin{tabular}{|c|c|c|c|c|c|}
\hline \multicolumn{2}{|c|}{ 住居移動 } & \multicolumn{2}{|c|}{ その他の居住地移動 } & \multirow{2}{*}{$\begin{array}{l}\text { 移動経験 } \\
\text { なし }\end{array}$} & \multirow[b]{2}{*}{ 合 計 } \\
\hline 都市間 & 都市内 & 職業的理由 & その他 & & \\
\hline $\begin{array}{c}491 \\
(30.6)\end{array}$ & $\begin{array}{c}779 \\
(48.5)\end{array}$ & $\begin{array}{l}143 \\
(8.9)\end{array}$ & $\begin{array}{c}147 \\
(9.1)\end{array}$ & $\begin{array}{c}47 \\
(2.9)\end{array}$ & $\begin{array}{c}1,607 \\
(100.0)\end{array}$ \\
\hline
\end{tabular}

単位は世帯, 括弧内は\%。「「の他」には，婚姻によるものや 自営業者の居住地移動が含まれる.

(アンケート結果より作成). 


\section{III 国勢調查の結果からみた千葉市への人口流入}

千葉市の市域は JR 東京駅を中心とした半径 40 $\mathrm{km}$ 圈に含まれ，東京区部までの時間距離は 40〜 60 分である. そのため，千葉市は，高度経済成長 期以降，人口の郊外化に伴い東京との関連を強めて きた．常住地べースで全就業者に占める東京区部就 業者の比率をみると, 1965 年には $17.4 \%$ であった ものが 1985 年には $24.7 \%$ にまで上昇した. しかし， その一方で就業地ベースでの千葉市就業者数は，15 万人から 31 万人にまで増加し，千葉市の通勤圈は 拡大している4)。また，年間卸売業販売額をみると， 1970 年には千葉県全体に占める割合が $35.1 \%$ であ ったのに対し，1985 年には $44.9 \%$ まで上昇し，千 葉県内での中心地性を高めている．東京大都市圏に 組み込まれつつ, 自市における就業機会を增大させ， 中心地性を高めている千葉市は，東京大都市圈内に おいて新たな都市化中心となっている代表的な都市 の 1 つであるといえるであろう.

千葉市における全流入人口の変化を 1970 年と 1980 年の国勢調查によるデータからみてみる（第 2 表).これらの移動デー夕には，本研究では扱わ ない職業的理由に基づく居住地移動も含まれること に注意しなければならないが，仮に東京都およびそ の隣接 3 県に前居住地をもつものを東京大都市圈内 での居住地移動，それ以外を東京大都市圈外からの 居住地移動とするならば，通勤距離によって移動範
囲が制限される住居移動は，東京大都市圏内での居 住地移動にその大部分が含まれると思われる.

この東京大都市圈内での居住地移動をさらに, 中

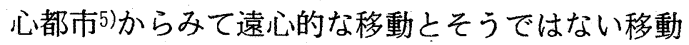
とに分けて分析すると，1970 年には東京区部およ び JR 総武沿線都市 (市川市, 船橋市, 習志野 市）からの移動が，千葉市への流入の $34.9 \%$ を占 めていたのに対し，1980 年には $32.4 \%$ に低下した. とくに，東京区部からの流入は絶対数でも 13, 505 人から 9, 219 人に低下し, 全流入人口に占める割合 も $24.5 \%$ から $18.9 \%$ まで低下した，一方，非遠心 的移動之捉えられる居住地移動（神奈川県, 埼玉県, 区部を除いた東京都, 総武線沿線都市を除いた干葉 県) の比率は, 1970 年には $36.2 \%$ あったものが 40.5\%まで上昇している. また, 神奈川県, 埼玉県 および区部を除いた東京都に前居住地をもつ移動に ついては, 絶対数のうえでも増加傾向にある.

以上のことは, 千葉市では 1970 年以降，中心都 市から放射状に広がる鉄道路線網によって規定され るセクター内で行なわれる移動（矢野，1989）の比 率は縮小し, 東京大都市圈全域からの移動が活発に なっていることを示すものである.

\section{IV 移動方向からみた世帯属性の差異}

分析対象となった 444 世帯の前居住地は，千葉県 各地と東京都, 神奈川県の東部および埼玉県南東部 に分布している(第 1 図). 中学校にアンケート用

第 2 表 千葉市への流入人口の変化

Table 2 Changes of in-migration in Chiba City

\begin{tabular}{|c|c|c|c|c|c|c|c|c|}
\hline \multirow{3}{*}{ 前䧹地 } & \multicolumn{6}{|c|}{ 東京大都市圏内での移動 } & \multirow{3}{*}{ 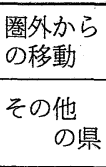 } & \multirow[b]{3}{*}{ 合 計 } \\
\hline & \multicolumn{2}{|c|}{ 遠心的移動 } & \multicolumn{4}{|c|}{ 非遠心的移動 } & & \\
\hline & 東京区部 & $\begin{array}{l}\text { JR総武線 } \\
\text { 沿線都市 }\end{array}$ & $\begin{array}{l}\text { その他の } \\
\text { 千 葉 県 }\end{array}$ & 神奈川県 & 埼玉県 & $\begin{array}{l}\text { その他の } \\
\text { 東 京.都 }\end{array}$ & & \\
\hline 1970 年 & $\begin{array}{l}13,505 \\
(24.5)\end{array}$ & $\begin{array}{r}5,740 \\
(10.4)\end{array}$ & $\begin{array}{l}12,620 \\
(22.9)\end{array}$ & $\begin{array}{r}2,025 \\
(3.7)\end{array}$ & $\begin{array}{r}3,300 \\
(6.0)\end{array}$ & $\begin{array}{r}1,990 \\
(3.6)\end{array}$ & $\begin{array}{l}15,860 \\
(28.8)\end{array}$ & $\begin{array}{l}55,040 \\
(100.0)\end{array}$ \\
\hline 1980 年 & $\begin{array}{r}9,219 \\
(18.9)\end{array}$ & $\begin{array}{r}6,616 \\
(13.5)\end{array}$ & $\begin{array}{l}11,551 \\
(23.6)\end{array}$ & $\begin{array}{r}2,376 \\
(4.9)\end{array}$ & $\begin{array}{r}3,505 \\
(7.2)\end{array}$ & $\begin{array}{r}2,338 \\
(4.8)\end{array}$ & $\begin{array}{l}13,277 \\
(27.2)\end{array}$ & $\begin{array}{l}48,882 \\
(100.0)\end{array}$ \\
\hline
\end{tabular}

単位は人，括弧内は\%。 

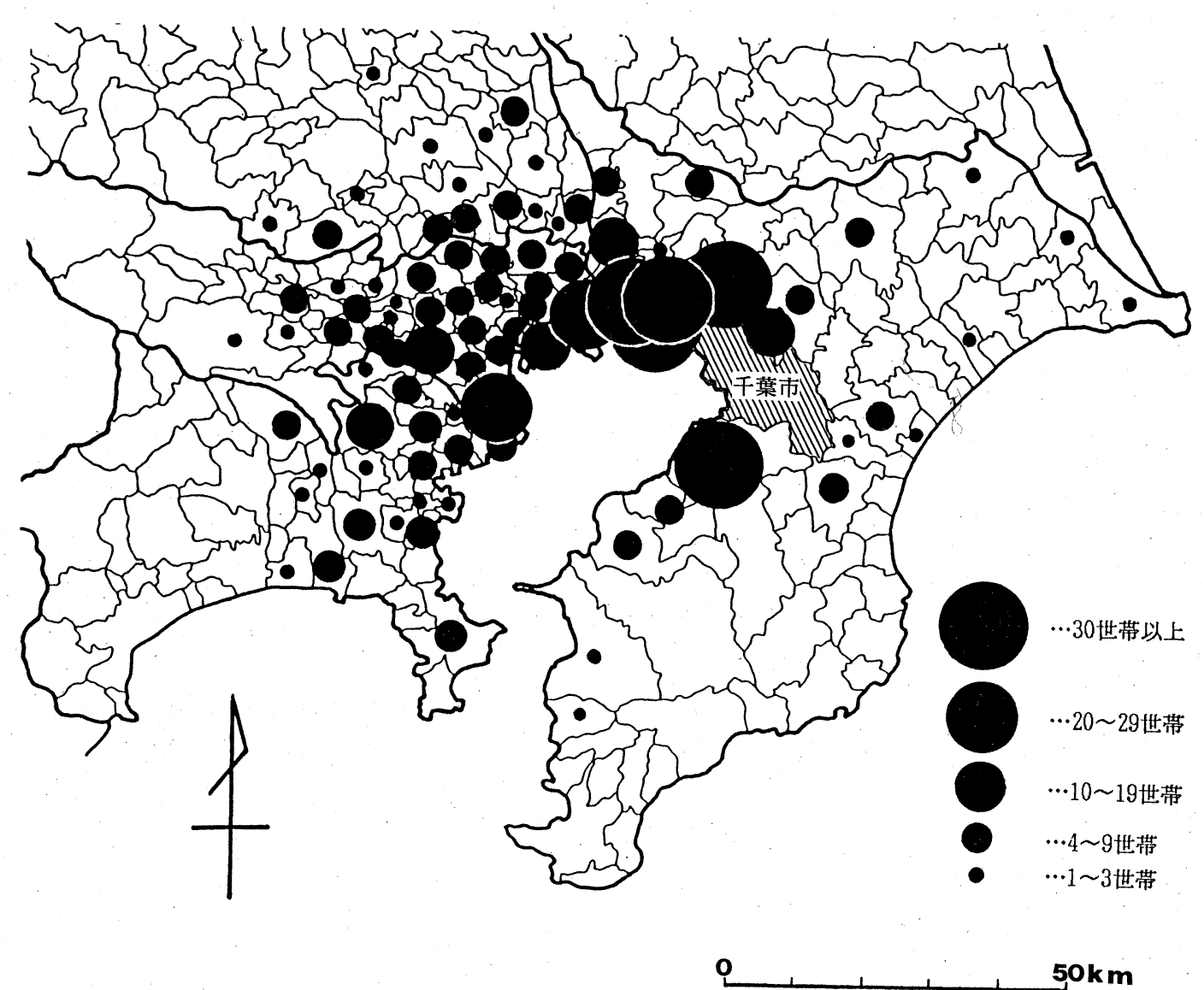

第 1 図住居移動を行なった世帯の前居住地の分布 (アンケート結果より作成).

Fig. 1 Distribution of the previous residence of the residential mobility

紙を配布した関係上，分析対象は中学生を子供にも つ世帯に限定されるため, 第 1 図に示された前居住 地の分布が，千葉市へ住居移動してくるすべての移 動世帯の移動パ多ーンを直接反映しているとはいえ ない. しかし，距離的制約を強く受けるといった住 居移動の特性を考えると, 他の移動世帯の前居住地 も図に示された前居住地の分布から大きく外れるこ とはないと思われる。本研究では, 上記の地域を千 葉市の住居移動圈と呼ぶことにする.

国勢調查の報告から得られた結果同様, 移動世帯 の前居住地は東京区部之千葉市を結ぶ地域に集中し ていることは明らかである. 千葉市を着地とする住
居移動の移動方向に関する議論を容易にするために, 対象世帯の移動を前居住地別に東京区部からの移動 (以下, 「東京区部」), 市川市, 船橋市, 習志野市之 いった JR 総武線沿線都市からの移動（以下，「総 武線沿線」),「総武線沿線」を除く千葉県内からの 移動（以下，「県内」），上の 3 つの地区を除いた地 区からの移動（以下，「その他」）の 4 グループに分 類してみると，「東京区部」が 122 世帯 (27.5\%), 「総武線沿線」が 119 世帯 (26.8\%), 「県内」が 127 世帯 (28.6\%),「その他」が 76 世帯 (17.1 \%) となる. 国勢調查による結果よりも東京区部, $\mathrm{JR}$ 総武線沿線都市からの移動の比率が高いのは, 
第 3 表 移動による部屋数の変化

Table 3 Changes in the number of rooms as a result of moving

\begin{tabular}{|c|c|c|c|c|c|c|c|}
\hline 前住居 現住居 & 1 部屋 & 2 部屋 & 3 部屋 & 4 部屋 & 5 部屋 & 6 部屋 & 計 \\
\hline 1 部屋 & & & 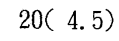 & 19 & 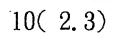 & $3(0.7)$ & $56(12.6)$ \\
\hline 2 部屋 & $1(0$ & $10(2.3)$ & $67(15$ & $51(1$ & $38(8.6)$ & $15(3.4)$ & $182(41.0)$ \\
\hline 3 部屋 & ) & $3(0.7)$ & $38(8.6)$ & $74(1$ & $39(8.8)$ & $12(2.7)$ & $166(37.4)$ \\
\hline 4 部屋 & $0(c$ & $3(0$ & & $10 c$ & $6(1$. & & $27(\quad 6.1)$ \\
\hline 5 部屋 & $0<0$ & $0(0.0)$ & 1( & & 2( & & $7(1.6)$ \\
\hline 6 部屋 & $0(0.0)$ & $0(0.0)$ & $2(0.5)$ & $2(0.5)$ & $0(0.0)$ & $2(0.5)$ & $6(\cdot 1.4)$ \\
\hline 合 計 & $1(0.2)$ & $27(6.1)$ & $133(30.0)$ & $53(34.5)$ & $95(21.4)$ & $35(7.9)$ & $444(100.0)$ \\
\hline
\end{tabular}

単位は世帯, 括弧内は\%。

(アンケート結果より作成).

対象を住居移動を行なった世帯に限定しているため に長距離の移動が含まれていないためと思われる。 しかし，それでも「県内」と「その他」の比率を合 わせると $45.7 \%$ (203 世帯) を占め, 住居移動に限 定しても遠心的移動のみが千葉市の人口流入を説明 するわけではないことを示している.

移動による部屋数の变化をみると, 移動後に部屋 数の増えた世帯は 81.3\% (361 世帯) に達するのに 対し, 部屋数の減った世帯は $4.7 \%$ (21 世帯) にす ぎない(第 3 表)6)．このように, 部屋数の増加 (居 住面積の増大）が住居移動の大きな要因となってい ることは明らかである. さらに, 部屋数の増えた世 帯の $75.1 \%$ (271 世帯) が, 1 部屋または 2 部屋の 増加であり, 居住面積の拡充が段階的に行なわれて いることがわかる. 前居住地別にみると,「東京区 部」は, 2 部屋以下の住居からの移動が全体の
67. 2\% (82 世帯). を占めるのに対し, 「県内」は $36.2 \%$ (46 世帯) である. また， 5 部屋以上の部屋 数をもつ住居への移動は，「東京区部」で $24.6 \%$ (30 世帯), 「県内」で 31.5\% (40 世帯) である. 「総武線沿線」および「その他」は，両者の中間に 位置するが,「総武線沿線」は「東京区部」に,「そ の他」は「県内」に近い傾向を示し，遠心的な移動 ほよ゙小規模住居間での移動が多い.

住居形態の変化について, 移動後の住居形態をみ ると，戸建ての持ち家への移動が 61.0\%（271 世 帯), 集合住宅の持ち家への移動が 15.1\%（67世 帯）を示し，住宅の購入が周辺地域における住居移 動の動機となっていることがわかる(第 4 表)7). とくに，「その他」においては戸建ての持ち家への 移動が 72.4\% (55 世帯) を示す.「総武線沿線」で は, 公営住宅への移動が全体の約 $20 \%$ 占めてお

第 4 表 移動による住居形態の变化

Table 4 Changes in the type of housing with the move

\begin{tabular}{|c|c|c|c|c|c|c|c|}
\hline 前住居 現住居 & 戸建て & 集合住宅 & 民間借家 & 公営住宅 & 給与住宅 & 親族の家 & 計 \\
\hline 戸建 て & $26(5.9)$ & $2(0.5)$ & $0(0.0)$ & $1(0.2)$ & $2(0.5)$ & $3(0.7)$ & $34(7.7)$ \\
\hline 集合住宅 & $17(3.8)$ & $11(2.5)$ & $0(0.0)$ & $0(0.0)$ & $0(0.0)$ & $1(0.2)$ & $29(6.5)$ \\
\hline 民間借家 & $70(15.8)$ & $16(3.6)$ & $7(1.6)$ & $51(11.5)$ & $4(0.9)$ & $3(0.7)$ & $151(34.0)$ \\
\hline 公営住宅 & $61(13.7)$ & $11(2.5)$ & $3(0.7)$ & $11(2.5)$ & $1(0.2)$ & $1(0.2)$ & $88(19.8)$ \\
\hline 給与住宅 & $77(17.3)$ & $23(5.2)$ & $2(0.5)$ & $2(0.5)$ & $9(2.0)$ & $1(0.2)$ & $114(25.7)$ \\
\hline 親族の家 & $20(4.5)$ & $4(0.9)$ & $1(0.2)$ & $1(0.2)$ & $1(0.2)$ & $1(0.2)$ & $28(6.3)$ \\
\hline 合 計 & $271(61.0)$ & $67(15.1)$ & $13(2.9)$ & $66(14.9)$ & $17(3.8)$ & $10(2.3)$ & $444(100.0)$ \\
\hline
\end{tabular}


り, 住宅購入以外の理由による移動が他の地域に比 べて比較的多くみられる. 一方, 移動前の住居形態 は，民間借家からの移動が 34.0\% (151 世帯) と最 も多く, 次いで給与住宅の $25.7 \%$ (114 世帯), 公 営住宅の 19.8\% (88 世帯). となっている. 戸建て, 集合住宅ともに持ち家からの移動が少ないのは，住 宅購入を住居移動における最終ステップとする世帯 が多いためと思われる. 前居住地別にみると, 「東 京区部」および「総武線沿線」では民間借家からの 移動が全体の $40 \%$ を越えるのに対し，「県内」では， 給与住宅からの移動が $32.3 \%$ (41 世帯), 公営住宅 からの移動が $22.8 \%$ (29 世帯) であり，民間借家 からの移動は $20.5 \%$ (26 世帯) と低い。さらに, 戸建ての持ち家からの移動も12.6\% (16 世帯) と なっており，他のグループに比べ移動前の住居形態 が多様化している。

大都市圈に含まれる都市が圈外の都市と大きく異 なる点は，居住している都市ではなく中心都市に就 業地をもつ住民が多いということである. 分析対象 となった世帯においても，世帯主の就業地を干葉市 にもつ世帯は，全体の $18.5 \%$ (82 世帯) である(第 5 表)，とくに，「その他」では，世帯主の就業地を 千葉市にもつ世帯は $5.3 \%$ (4 世帯) にすぎず，東 京区部に世帯主の就業地をもつ世帯が $80 \%$ 以上を 占める.千葉市の住居移動圈は東京区部を越えて東 京大都市圈の西部まで広がっているが，このような
第 5 表 前居住地別にみた世帯主の就業地 Table 5 Workplace of the household head by previous residence

\begin{tabular}{c|rrr|r}
\hline 前居住地 通勤地 & 千葉市内 & 東京区部 & その他 & 合 計 \\
\hline 東京区 部 & $17(13.9)$ & $83(68.1)$ & $22(18.0)$ & $122(100.0)$ \\
総武線沿線 & $23(19.3)$ & $61(51.3)$ & $35(29.4)$ & $119(100.0)$ \\
県 内 & $38(29.9)$ & $51(40.2)$ & $38(29.9)$ & $127(100.0)$ \\
その 他 & $4(5.3)$ & $63(82.9)$ & $9(11.8)$ & $76(100.0)$ \\
\hline 合 計 & $82(18.5)$ & $258(58.1)$ & $104(23.4)$ & $444(100.0)$ \\
\hline
\end{tabular}

単位は世帯, 括弧内は\%。東京区部」,「総武線沿線」,「県 内」，「その他」の分類は本文に準ずる.

(アンケート結果より作成).

西方への住居移動圏の広がりは東京区部就業者の移 動によって形成されているところが大きい，一方， 東方への住居移動圈の広がりを意味する「県内」か らの移動については, 東京区部に世帯主の就業地を もつ世帯が $40.2 \%$ (51 世帯), 千葉市に世帯主の就 業地をもつ世帯が 29.9\% (38 世帯) と, 他の移動 に比べて千葉市就業者の比率が高くなる。

移動時期別に前居住地の比率をみると（第 6 表), 10 年前においては遠心的移動である「東京区部」

と、総武線沿線」が $60 \%$ 近くを占めていたのに対 し，過去 5 年間では非遠心的移動である「県内」と 「その他」が全体の半数以上を占めるようになって いることがわかる.千葉市における住居移動圈の広 がりという観点からみると，それは拡大傾向にある といえるであろう。「その他」と「県内」における 世帯主の就業地の違いと併せて，このことは住居移

第 6 表 前居住地別にみた移動時期

Table 6 Period of the moving by previous resindence

\begin{tabular}{|c|c|c|c|c|}
\hline 前居住地 & 10年以上前 & $5 \sim 10$ 年前 & $0 \sim 5$ 年前 & 計 \\
\hline 東京区部 & $68(28.3)$ & $40(28.0)$ & $14(23.0)$ & $122(27.5)$ \\
\hline 総武線沿線 & $74(30.9)$ & $30(21.0)$ & $15(24.6)$ & $119(26.8)$ \\
\hline 県 & $62(25.8)$ & $45(31.4)$ & $20(32.7)$ & $127(28.6)$ \\
\hline その 他 & $36(15.0)$ & $28(19.6)$ & $12(19.7)$ & $76(17.1)$ \\
\hline 合 計 & $240(100.0)$ & $143(100.0)$ & $61(100.0)$ & $444(100.0)$ \\
\hline
\end{tabular}

調査日 1987 年 7 月を起点とする. 単位は世帯, 括弧内は\%.「東京区 部」、「総武線沿線」,「県内」,「その他」の分類は本文に準ずる.

(アンケート結果より作成). 
動の移動距離に関係していると思われるが，それに ついては次章で詳しく述べる.

\section{V 移動距離の規定要因}

本章では，千葉市の住居移動圈の広がりを個々の 住居移動の移動距離から考察する. 個々の移動は, 移動世帯のもつ属性が多重的に影響しあって生じる ものであり，単一の属性と移動状況とを対応させて 各属性の移動に与える影響を議論することは難しい (堤，1989）。そこで，本研究では，各世帯属性が移 動距離に与える影響をできるだけ個別的にみるため に, 移動距離を目的变数, アンケート結果から得ら れた移動時における世帯主年齢および世帯人員, 前 住居での居住年数，移動時期，移動前之移動後の住 居形態および部屋数, 情報源, 候補地の数, 自家用 車の有無, 世帯主の就業地の 12 の世帯属性を説明 変数として数量化 I 類の分析を行なった。この数量 化 I 類の分析によって理論的に導き出される移動距 離之実際の移動距離との相関係数は 0.465（1％水 準で有意)であった．なお，移動距離については前 居住地から現居住地までの直線距離とした．全移動 世帯の示した移動距離の平均値（以下，平均移動距 離と㭔ぶ）は $27.7 \mathrm{~km}$ である。

分析の結果得られたレンジ長をみると, 12 の世 帯属性のうち移動距離に対して強い影響を与えてい るのは, 移動前後の住居形態, 情報源, 世帯主の就 業地であった（第 7 表）. 以下， 10.00 以上のレン ジ長を示す上位 4 つの世帯属性について, 移動距離 との関係を考察する.

第 1 位のレンジ長を示す現在の住居形態について 各住居形態の示すカテゴリースコアをみると，正の 值をとるのは戸建ての持ち家と親族の家である（第 2 図). 戸建ての持ち家への移動が正のカテゴリー スコアを示すのは，前述したように移動距離が長く なる神奈川県，埼玉県および区部を除いた東京都か らの移動の大半が戸建て住宅への移動であるためで
第 7 表 数量化 I 類の分析によっ て得られた各世帯属性の レンジ長

Table 7 Range of the household attributes by Quantification Theory I

\begin{tabular}{c|l|c}
\hline . 順位 & 世帯属性 & レンジ \\
\hline 1 & 現住居形態 & 13.30 \\
2 & 前住 居形態 & 13.27 \\
3 & 情 報 源 & 11.11 \\
4 & 通 勤 先 & 10.98 \\
5 & 世帯 人 員 & 9.73 \\
6 & 部屋数 (現) & 8.96 \\
7 & 部屋数 (前) & 7.94 \\
8 & 候 補 地 & 7.79 \\
9 & 居 住 年 数 & 4.33 \\
10 & 自動車の保有 & 4.05 \\
11 & 移 動 時 期 & 3.51 \\
12 & 世帯主年 齢 & 1.63 \\
\hline
\end{tabular}

全移動世帯が示す移動距離の平均值は $27.7 \mathrm{~km}$ である.

(アンケート結果より作成).

ある8). 東京大都市圈の西部からの移動になぜ戸建 ての持ち家への移動が多いのか, という点について は, 圈域内部における住宅市場の地域性について調 査, 分析する必要があり,ここで明確な根拠を提示 することはできない.しかし，民間借家，公営住宅， 給与住宅の家顀や高度利用によって敷地を共有する 集合住宅の価格に比べ，戸建て住宅の価格は，圈域 内部における地価分布により強く影響を受けるもの と考えられる．地価分布に西高東低の傾向がある東 京大都市圈において（山田，1991），戸建て住宅の 購入を考える移動世帯は, 通勤距離という制約条件 のもとで地価が相対的に安い東部地域を移動先とす る場合が多いと解釈できる．また，親族の家への移 動は, 他の住居形態への移動に比べて移動世帯に選 択の余地はない，どこに住んでいようとも親族の家 に移動することが決まった時点で，親族の家のある 千葉市に移動せざるをえないこととなるため, 他の 住居形態への移動に比べて長距離の移動になりやす いと考えられる.

第 2 位のレンジ長を示すものとして抽出された属 


\begin{tabular}{|c|c|c|}
\hline カテゴリー & 世帯数 & カテゴリースコア \\
\hline 戸 建 て & 271 & 2.73 \\
\hline 集合住宅 & 67 & -5.12 \\
\hline 民間 借家 & 13 & -4.29 \\
\hline 公営住宅 & 66 & -6.31 \\
\hline 給 与住宅 & 17 & -0.19 \\
\hline 親族 の家 & 10 & 6.99 \\
\hline
\end{tabular}

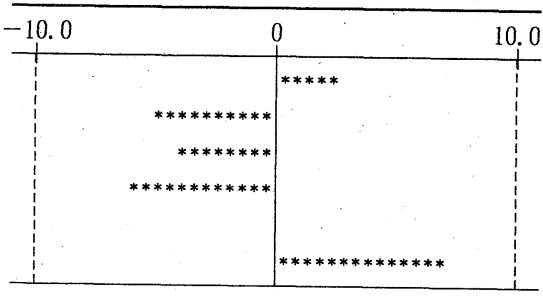

前住居形態

\begin{tabular}{lr|r|c}
\hline \multicolumn{2}{|c|}{ カテゴリー } & 世帯数 & カテゴリースコア \\
\hline 戸 建 て & 34 & -6.67 \\
集 合 住 宅 & 29 & 0.08 \\
民 間 借 家 & 151 & 0.63 \\
公 営 住 宅 & 88 & -3.45 \\
給 与 住 宅 & 114 & 2.18 \\
親 族 の 家 & 28 & 6.60 \\
\hline
\end{tabular}

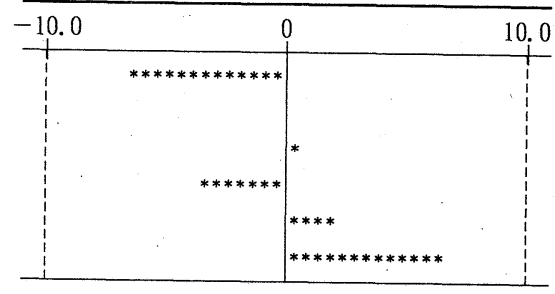

\begin{tabular}{|c|c|c|}
\hline カテゴリー & 世帯数 & カテゴリースコア \\
\hline T V・ラジオ & 15 & 1.49 \\
\hline 聞 & 153 & -1.01 \\
\hline 知 & 111 & -0.59 \\
\hline 会 & 35 & 3.71 \\
\hline 広 & 47 & 0.31 \\
\hline 不動産業者 & 55 & -2.28 \\
\hline 住宅情報誌 & 13 & 8.83 \\
\hline そ の 他 & 15 & 4. 26 \\
\hline
\end{tabular}

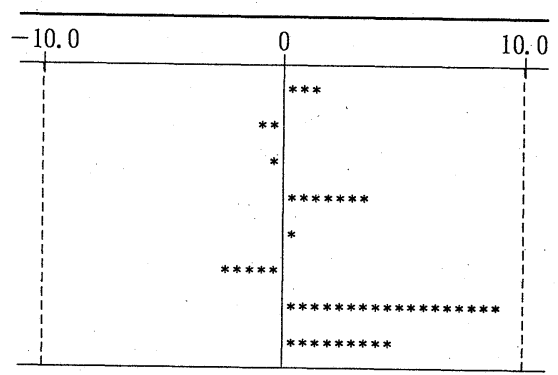

\begin{tabular}{|c|c|c|}
\hline カテゴリー & 世帯数 & カテゴリースコア \\
\hline 千 葉 市 & 82 & -4.54 \\
\hline 東京 23 区 & 258 & 4. 18 \\
\hline そ の 他 & 104 & -6.80 \\
\hline
\end{tabular}

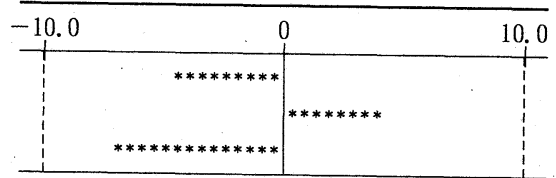

第 2 図 10.00 以上のレンジ長を示す世帯属性のカテゴリースコア (アンケート結果より作成)

Fig. 2 Category score of the household attributes showing a range of 10.00 or more

性は, 移動前の住居形態であり, 住居形態が移動距 離に与える影響は移動前後とも大きいことがわかる. 前住居の住居形態の示すカテゴリースコアをみると， 戸建ての持ち家への移動は, 移動距離を増大させ.る のに対し, 戸建ての持ち家からの移動は, 移動距離 を短縮させることがわかる. また, 他の住居形態の 示すカテゴリースコアをみると, 親族の家 $\rightarrow$ 給与住 宅 $\rightarrow$ 民間借家 $\rightarrow$ 持ち家 (集合住宅) $\rightarrow$ 公営住宅の順
に值が小さくなっている．都市生活者の行動は，彼 らが個々に形成している社会空間と密接に関連して いる (Chombart de Lauwe, 1960; Golledge and Stimson, 1987). そのため, 土地へのファミリア リティー（親地性）が高い世帯まど，そこで形成し てきた社会空間から離れたくないという意識が働き， 移動距離が短くなると考えられる。意志決定過程が 他の住居形態の移動世帯とは異なる公営住宅からの 
移動を除けば9，分析結果は持ち家に居住していた 世帯ほど土地へのファミリアリティーが高いことを 示しているといえる.

第 3 位のレンジ長を示す属性として抽出された情 報源についてみると，正のカテゴリースコアを示し たのは，T V・ラジオ，通勤先の会社（給与住宅 等)，広報 (自治体広報)，住宅情報誌，その他であ り, 負のカテゴリースコアを示したのは, 新聞, 知 人，不動産業者である．家にいながら関東一円のお おまかな住宅情報（家賃，地価の相場）が把握でき る住宅情報誌が高いカテゴリースコアを示し，局地 的な情報を提供する不動産業者が最も低いカテゴリ 一スコアを示していることから, 探索行動の範囲が 実際の移動距離と密接に関連しているといえる. 現 在, 住宅情報誌よりもさらに広範囲で大量の情報を 提供するコンピュータ・ネットワークシステムが不 動産業界に導入され始めている.このシステムが, 今後, 整備充実されれば, 不動産業者を情報源とし て利用する移動世帯の探索行動の範囲は増大するで あろうし，それに伴って移動距離も増大するものと 考えられる.

第 4 位のレンジ長を示す世帯主の就業地では，東 京区部が高い正のカテゴリースコアを示し, 千葉市 およびその他の都市が負のカテゴリースコアを示し た. これは, 住居移動が通勤距離によって規定され ていることを裏付けるものであるが，就業地によっ て移動距離に差異が生じるということは, 移動時に おいて許容される通勤距離 (以下, 許容通勤距離と 呼ぶ）が就業地によって異なるということを意味し ている.もちろん，この許容通勤距離は個々の移動 世帯によって異なるものであるが, 就業地別の差異 は就業地となる都市の通勤圈の大小として現われ る10)。千葉市よりもその他の都市（おもに市川市, 船橋市, 習志野市) の方が低いカテゴリースコアを 示したのも，その他の都市が千葉市より規模の小さ な都市であり，その通勤圏が千葉市よりも狭いから
であろう．地方の都市に比べて居住者の就業地が多 様化している大都市圏内の都市では，中心都市，自 都市，近接する都市の通勤圈が重なりあっており， その大きさもそれぞれ異なる. その結果, 大都市圈 内の都市では, 許容通勤距離の異なるさまざまな移 動世帯によって広範囲な住居移動圈が形成されると 考えられる. 世帯主の就業地別に平均移動距離をみ ると, 千葉市およびその他の都市に世帯主の就業地 をもつ世帯グループの平均移動距離はそれぞれ $22.0 \mathrm{~km}$ (s=16.0, s は標準偏差), $21.1 \mathrm{~km}$ (s =16.1）であるのに対し, 東京区部に世帯主の就業 地をもつ世帯グループの平均移動距離は $32.2 \mathrm{~km}$ （ $\mathrm{s}=17.9 ）$ となり，世帯主の就業地によって平均移 動距離に $10 \mathrm{~km}$ 以上の差異が現われる. 数量化理 論によって理論的に導き出される移動距離と実際の 移動距離との相関係数が, 有意ではあるものの 0.465 之低いのは, 許容通勤距離が大きく異なる世 帯グループを混在させて分析を行なったことに原因 があるものと思われる. そこで，世帯主の就業地別 に移動世帯を分け，それぞれについて再び数量化 I 類の分析を行なった.

その結果, 世帯主の就業地を千葉市にもつ世帯グ ループと世帯主の就業地をその他の都市にもつ世帯 グループでは, 数量化理論によって理論的に導き出 される移動距離と実際の移動距離との相関係数が, それぞれ 0.732，0.763（1％水準で有意）となり， 全移動世帯に対して行なった分析結果よりもかなり 上昇した。 また，移動距離に影響を与える世帯属性 についても，移動前後の住居形態と情報源が移動距 離に対して高い影響力をもつ属性として抽出され (第 8 表)，そのカテゴリースコアの傾向も大きな違 いはみられなかった。

しかしながら，世帯主の就業地を東京区部にもつ 世帯グループに関しては，居住面積を示すものとし て採用した移動前後の部屋数が移動距離に大きな影 響を与える属性として抽出され，この世帯グループ 
第 8 表 世帯主の就業地別にみた各世帯属性のレンジ長

Table 8 Range of the household attributes by Quantification Theory I and by the workplace of the household head

\begin{tabular}{|c|c|c|c|c|c|c|}
\hline \multirow{2}{*}{ 順位 } & \multicolumn{2}{|c|}{ 千葉市 } & \multicolumn{2}{|c|}{ 東京区部 } & \multicolumn{2}{|c|}{ その他 } \\
\hline & 世帯属性 & レンジ & 世帯属性 & レンジ & 世帯属性 & レンジ \\
\hline 1 & 現住居形態 & 45.94 & 現住居形態 & 14.03 & 現住居形態 & 40.90 \\
\hline 2 & 前住居形態 & 45.08 & 部屋数 (前) & 13.16 & 前住居形態 & 34.44 \\
\hline 3 & 世带人員 & 33.25 & 前住居形態 & 11.41 & 情 報 源 & 29.16 \\
\hline 4 & 情 報 源 & 28.79 & 部屋数（現） & 11.00 & 自動車の保有 & 19.87 \\
\hline 5 & 移 動 時 期 & 28.70 & 情 報 源 & 10.46 & 移 動 時 期 & 12.08 \\
\hline 6 & 部屋数（前） & 23.68 & 候補 地 & 10.10 & 世帯人員 & 11.82 \\
\hline 7 & 部屋数（現） & 17.98 & 世帯主年齢 & 8.23 & 部屋数（現） & 11.67 \\
\hline 8 & 候 補、地 & 17.98 & 移 動 時 期 & 8.08 & 部屋数（前） & 10.75 \\
\hline 9 & 自動車の保有 & 11.32 & 世帯人員 & 4.00 & 候 補 地 & 9.33 \\
\hline 10 & 居 住 年 数 & 8.98 & 居住年 数 & 2.73 & 居住 年 数 & 8.42 \\
\hline 11 & 世帯主年齢 & 3.29 & 自動車の保有 & 2.64 & 世帯主年齢 & 7.26 \\
\hline
\end{tabular}

の移動が居住面積に対して敏感に反応することが明 らかとなった. さらに, 数量化理論によって理論的 に導き出される移動距離と実際の移動距離との相関 係数も 0.458 ( $1 \%$ 水準で有意) となり，他の $2 つ$ の世帯グループに対して行なった分析結果に比べて 移動距離と世帯属性の関係が不明確である。これは, この世帯グループに関しては本研究で扱った世帯属 性以外にも移動距離に影響を与える属性が存在する ことを示唆するものである. 平均移動距離の長さか ら示されるように, この世帯グループの住居移動は 広範囲にわたるため, 東京大都市圏における住宅市 場の地域性が関連しているように思われる.

\section{VI ま と}

以上，本研究では，通勤距離によって制約を受け る住居移動を取り上げ, 千葉市を事例として東京大 都市圏内で行なわれる居住地移動の特性を移動世帯 の属性から分析してきた. その結果, 次のような結 果が得られた。

1）千葉市の住居移動圈は東京大都市圈のほぼ全 域と千葉県東部にまで広がっており, 千葉市への住 居移動を東京方面からの遠心的移動だけで説明する ことはできなくなっている. 全住居移動に占める比 率をみても，遠心的移動の比率は年々低下し，近年
では非遠心的移動が過半数を占めるようになった。

2）住居移動における最も大きな移動理由は，住 宅の購入であり, 移動先の住居形態を戸建ての持ち 家とする移動は全体の約 $60 \%$ を占める。 とくに, 神奈川県, 埼玉県および区部を除く東京都から千葉 市に流入する世帯の移動は，ほとんどが住宅購入に よる移動であり，集合住宅への移動を含めると全体 の約 $80 \%$ に達する. 移動距離の面からみても，移 動前後の住居形態は, 移動距離に最も大きな影響を 与える世帯属性である.

3）居住地決定のための情報源は, 移動前後の住 居形態に次いで移動距離に影響を与える属性であり, 不動産情報の広域化が，大都市圈内の都市における 住居移動圏を拡大する要因の 1 つとなっている.

4）通勤距離が最大の制約条件である住居移動に とって，大都市圏居住者における就業地の多様性は， 移動距離之世帯属性との関係にも差異を生じさせて いる. とくに, 東京区部に世帯主の就業地をもつ世 帯は東京大都市圈西方からの移動が多く, 平均移動 距離が他の世帯の平均移動距離よりも長い. また, 世帯属性が移動距離に与える影響についても, 他の 世帯に比べ, 今回の分析で用いた属性からでは説明 しきれない部分が多い.

本研究では，世帯属性から東京大都市圏内で行な 
われる住居移動の特性を考察してきたが，移動先決 定またはそこにいたるまでの過程において直接影響 を与えるような情報源や価格（あるいは家賃）から みた分析が今後必要亡なるであろう，とくに，住宅 の購入が移動の大半を占める大都市圈内での住居移 動においては, 経済的要因が移動先決定に大きなウ エイトを占めていると考えられる.また，世帯属性 に関しても，今回の分析では世帯主の属性をもって それを代表させている部分が多いが，現在は共稼ぎ の世帯も多く，今後一層主婦の意志が移動に影響し てくることは，十分に考えられる.川口（1990）の 研究によれば，世帯主の就業地が東京区部にある世 帯であっても，主婦の東京指向は低下する傾向にあ り, 同一世帯においてもその構成員の生活空間に差 異が生じてきている. 今後の調査では主婦の行動に ついても調查する必要があろう.

本稿の作成に当たり, 御指導いただきました仙台大学 板倉勝高教授, 東北大学島田周平教授, 日野正輝助教授 に深く感謝いたします，また，現地調査の際にお世話い ただきました千葉市の都市計画課の皆様にも，記して厚 く御礼申し上げます.なお，本稿の骨子は 1990 年 4 月 の日本地理学会春季学術大会で発表した.

（投稿 1991 年 12 月 5 日） （受理 1992 年 9 月 12 日）

\section{注}

1) 渡边 (1978a, b) は, 東京大都市圈内の構造的な変 容を周辺地域の人口増加を分析することによって論じ， 1960 年代後半においてすでに周辺地域が自己展開的な 発展段階に入ったことを指摘した，また，阿部（1982） は, 住宅, 工場, 大規模小売店などの分散が周辺地域に 新たな都市化中心を作り出しており, 東京を唯一の都市 化中心とする地域形成の時期は終わったと述べている. このような東京大都市圈の構造変容については, 富田 （1988），藤井（1990）が詳細に展望している.

2) 同報告によれば，たとえば青森県においては生活環境 上の理由に基づく居住地移動は全体の $10.0 \%$ にすぎず, 第 1 . 位の移動理由は家族・親族上の理由である(46.2 $\%)$.

3) Brown and Moore（1970）による居住地の意志決定
モデルによれば, 居住地移動には移動者による2 度の意 志決定が反映される. そのため, 本研究でも前住居を出 た理由と現住居に入った理由に分けて移動理由に対する 質問を行なった．しかし，回答者は，それほじ明確に 2 度の意志決定を意識しておらず, 1 回目の意志決定と 2 回目の意志決定を混同している回答が多数みられた。そ こで, 本研究では $2 つ の$ 移動理由をま之めて, 住居移動 であるか否かの判別に使用し, 移動理由からの分析はほ とんど行なわなかった.

4) 千葉市への通勤率が 10\%を越える市町村は，1965 年 の時点では 1 市町村にすぎなかったが, 1985 年には 10 市町村にまで増加した。 また，その形状は，千葉市を中 心とした同心円というよりも，千葉市南部，および南西 部に偏った広がりをみせる。

5) 本研究では, 東京区部を東京大都市圈における中心都 市とする。

6 ) 前居住地別にみると, 部屋数の減った世帯は, 「東京 区部」で 6.6\% (8 世帯),「総武線沿線」で $0.0 \%(0$ 世帯), 「県内」で $6.3 \%$ ( 8 世帯), 「その他」で $6.6 \%$ ( 5 世帯) である.

7 ) 戸建てと集合住宅を合わせた持ち家への移動比率を前 居住地別にみると,「東京区部」が 72.9\% (89 世帯), 「総武線沿線」が $73.1 \%$ (87 世帯)，「県内」が $77.1 \%$ (98 世帯),「その他」が $84.2 \%$ (64 世帯) である.

8 ）数量化 I類の分析は, 数量化されないデー夕（世帯属 性）にダミ一変数を適用し，数量化された値（移動距 離）を予測するためのものである. カテゴリースコアと は基本的にダミー变数の係数であり, 実測値と予測値と の差の 2 乗和を最小にするよう求められている。 そして 最大カテゴリースコアから最小カテゴリースコアを引い た値をレンジまたはレンジ長と呼んでいる。つまり，カ テゴリースコアが大きいほど予測される移動距離が長く なり,レンジ長が長いほどその世帯属性の移動距離に与 える影響が強いといえる. 戸建ての持ち家への移動が正 のカテゴリースコアを示すのは, 戸建ての持ち家への移 動を示したサンプルの多くが全体の平均移動距離よりも 長距離の移動を行なっていることにほかならない.

9) Smith and Ford（1985）は，英国バーミンガムにお ける公営住宅居住者の移動決定過程を分析し, 彼らの意 志決定が他の居住形態の居住者と異なることを指摘して いる.

10）就業地の異なる複数の就業者をもつ世帯においては, さらに移動可能な地域が限定されるものと思われるが, ここでは世帯主の就業地のみから分析を行なっている.

\section{文 献}

阿部 隆（1982）: 都市地域. 山崎謹哉編：『地域の地理 
学』大明堂, 119-137.

川口太郎 (1990) : 大都市圈の構造変化と郊外. 地域学研 究, 3 号, 101-113.

蒲生正久 (1979) : 大都市圏の拡大. 伊藤達也 - 内藤博 夫・山口不二雄編 :『人口流動の地域構造』大明堂, 197-208.

岸本 実 (1975) : 大都市の市街地における人口移動— 東京の場合一一地理月報, 214 号, 1-5.

人口問題研究所 (1991) : 11990人口の動向 日本と世界 一人口統計資料集——』厚生統計協会, $243 \mathrm{p}$.

堤 研二 (1989): 人口移動研究の課題之視点. 人文地理, 41, 529-550.

富田和暁 (1988) : わが国大都市圏の構造変容研究の現段 階之諸問題. 人文地理, 40,40-63.

藤井 正 (1983) : 都市地理学における大都市圏研究の再 検討一一その発展過程の解明にむけて—. 京都大学地 理学教室編：『空間・時間・イメージ』地人書房，37-56.

藤井 正 (1990): 大都市圈における地域構造研究の展望. 人文地理, $42,522-544$.

矢野桂司 (1989): 東京大都市圏内部の年齢階級別人口移 動パターン, 地理学評論, 62A, 269-288.

山田浩久 (1991): 東京大都市圈周辺地域における地価分 布とその変動. 経済地理学年報, 37, 354-368.
渡辺良雄 (1978a) : 最近の東京の膨張と都市問題への 1 ・ 2 の視点 第 1 部. 総合都市研究, 3号, 49-69.

渡辺良雄 (1978b) : 最近の東京の膨張と都市問題への 1 ・ 2 の視点 第 2 部. 総合都市研究, 3 号, 70-75.

渡辺良雄 (1978c) : 大都市居住亡都市内部人口移動. 総合 都市研究, 4 号, 11-35.

Adams, J. S. (1969): Directional bias in intraurban mobility. Econ. Geogr., 45, 302-323.

Brown, L. A. and Moore, E. G. (1970): The intraurban migration process: a perspective. Geogr. Ann., 52B, 1-13.

Chombart de Lauwe, P.-H. (1960): L'Evolution des besoins et la conception dynamique de la famille. Rev. Française de Sociologie, 1, 403-425.

Clark, W. A. V. (1985): Human migration. Scientific Geography Series, 7, 96p.

Golledge, R. G. and Stimson, R. J. (1987): Analytical behavioural geography. Croom Helm, London, 345p.

Smith, G. C. and Ford, R. G. (1985): Migration decisions of transfer applicants in the council housing sector. Environment and Planning A, 17, 153173.

\title{
Characteristics of Residential Mobility in the Suburban Areas of the Tokyo Metropolitan Area: A Case Study of Chiba City
}

\author{
Hirohisa YAMADA*
}

Migration can be classified as either regional migration or residential mobility, depending on the presence or absence of changes in migrants' jobs (Clark, 1985). Regional migration disrupts the general patterns of particular jobs by long-distance moves. Residential mobility does not necessarily disrupt job patterns, but involves short-distance moves to improve housing conditions. In order to understand the characteristics of residential mobility in the suburban areas of the Tokyo Metropolitan Area (M A.), this paper attempts to clarify the relationship between residential mobility and household attributes based on the direction and the distance of the move, using Chiba City as a case study. The results of the analysis are as follows: 
The relationship between the direction of residential mobility and household attributes: The migrants' residences before moving to Chiba City were distributed all over Chiba Prefecture, the eastern part of Kanagawa, the southeastern part of Saitama Prefecture, and the eastern part of the Tokyo Metropolis (Fig. 1). The author designates these areas of distribution as the residential mobility area of Chiba City.

All household moves are grouped into the following categories: 1) the 23 wards of Tokyo, 2) the areas along the Sobu Line, 3) other areas in Chiba Prefecture, and 4) all other moves'. The moves in Groups (1) and (2), which constitute about $55 \%$ of all moves, can be explained with the sectoral theory of Adams (1969). The moves in Groups (3) and (4), on the other hand, cannot be explained by Adams' theory. As the moves are analyzed in terms of the commuting destinations of household heads, the proportion of those who commute to Chiba City is higher for Group (3) than for the other three groups, while $83 \%$ of those belonging to Group (4) commute to the 23 wards of Tokyo (Table 5).

The relationship between the distance of residential mobility and household attributes: Hayashi's Quantification Theory I was applied in order to elucidate this relationship. It was found that the types of housing before and after the move were the most important determinants of the moving distance. The category score for each of the attributes shows that moving into one's own independent house lengthens the moving distance and that moving from one's own independent house shortens it (Fig. 2). The next important factor affecting the moving distance is the source of housing information. Moves based on housing information magazines result in a longer moving distance, because those magazines cover the entire Tokyo M. A.

The correlation coefficient between the calculated moving distance based on Quantification Theory I and the actual moving distance is 0.465 . Calculated on the basis of the commuting destination of household heads, the correlation coefficient for those commuting to Chiba City is 0.732 , for those commuting to the 23 wards of Tokyo 0.458 , and for those commuting to other areas 0 . 763 . The moving distance of households with the head commuting to Tokyo appears to be influenced by other factors as well.

Key words : Tokyo metropolitan area, Chiba city, migration, residential mobility, Quantification Theory I 